\title{
Isolation and Characterization of Salt-Tolerant Bacteria for Aquaculture Wastewater Treatment
}

\author{
Le Hung Anh ${ }^{1}$, Nguyen Hoang $\mathrm{My}^{2}$, Nguyen Khanh Hoang ${ }^{3}$, Vo Thi Kim Khuyen ${ }^{4}$ \\ ${ }^{1}$ Associate Professor, Institute of Environmental Science, Engineering and Management, Industrial University of Ho \\ Chi Minh City, Vietnam, lehunganh@iuh.edu.vn (First author) \\ ${ }^{2}$ Institute of Environmental Science, Engineering and Management, Industrial University of Ho Chi Minh City, \\ Vietnam, hoangmy554@gmail.com, \\ ${ }^{3}$ Institute of Environmental Science, Engineering and Management, Industrial University of Ho Chi Minh City, \\ Vietnam, nguyenkhanhhoang@iuh.edu.vn, \\ ${ }^{4}$ Institute of Waste Management and Circular Economy, Technische Universität Dresden, Germany, \\ kimkhuyenvo@gmail.com (Corresponding author)
}

\begin{abstract}
The water at the coastal fishing port shows high amount of COD due to the seafood exploitation and processing activities. The biological treatments are facing a challenge that is high salinity from 3 to $30 \mathrm{~g} / \mathrm{L}$ of the water because the high saline concentration could affect the growth of microbes commonly used in the treatment system. Thus, the treatment will become more effective in the presence of salt-tolerant microbes. In this study, total 45 species were isolated from seafood processing effluents in Tien Giang province, Vietnam, and cultured in BMS medium at 30\% and $\mathrm{pH}$ 7.0. The MALDI-TOF method was used to identify the isolated strains. As a result, the strains were characterized as Micrococcus luteus, Staphylococcus epidermidis, Bacillus cereus, Bacillus lichiniformis, Bacillus subtilis, Arthrobacter creatinolyticus and Lactobacillus pentosus with the similarity coefficients from 1.52. They were selected based on the highest tolerance in the range of $1-7 \%$ salinity to investigate their COD removal. The highest yield of COD removal was over $90 \%$ at the ratio of 1:5 (v/v) of bacteria to wastewater after 96-hour culture in the aerobic bioreactor. In conclusion, the results highlighted the potential applications of these species in the biological treatment of seafood processing wastewater.
\end{abstract}

Key words: salt-tolerant bacteria, halophiles, hypersaline aquaculture wastewater, seafood processing effluents.

\section{INTRODUCTION}

Wastewater discharged from domestic activities and many industries such as food processing, plant protection, pharmaceuticals, petroleum and textile productions contains very high concentrations of organic compounds, total dissolved solids (TDS) with at least 10,000-150,000 mg/L [1], and especially high salinity. The salt concentrations come from reactions in the medium and the origin of water. Thus, the salinity increases by the location of its water source. In the coastal provinces, the seawater is used for toilet-flushing, and cooling and other activities in residential communities, then discharged directly to the sea even without treatment commonly encountered in Vietnam. In addition, aquafarming has discharged untreated water from shrimp ponds to the nearby brackish seawater, such as in Can Gio province, Vietnam [2]. The amount of organic substances is quantified by the amount of chemical oxygen demand (COD) that is measured by potassium dichromate methods in the presence of silver sulfate catalyst in acidic environment [3]. The salinity and COD vary from 0.1 to $330 \mathrm{~g} / \mathrm{L} \mathrm{NaCl}$, and 800 to over $200000 \mathrm{mg} / \mathrm{L}$, respectively [4] depending on industrial activities. Amongst them, the wastewater from seafood processing has the range of saline amount of $13-65 \mathrm{~g} / \mathrm{L}[5]$, [6], and $150-42,000 \mathrm{mg} / \mathrm{L}$ COD [4]. The COD could be removed by chemical reactions; however, biological methods are more preferable because of their friendliness to human and environment.

The hyper-salinity poses several difficulties for determination of organic substances to water treatment system. The chloride $\left(\mathrm{Cl}^{-}\right)$ions causing the salinity are a significant interference of COD measurement. Therefore, dilution is essential prior to oxidation step in the COD analytical workflow. Nevertheless, the higher dilution factor can lead to too small COD amount below the linear range, inherent experimental errors and decrease in measurement accuracy and precision [7]. In addition, the salt amount that could not be removed completely during the treatment will produce potential adverse effects on the environment. Physio-chemical and biological approaches can be utilized to remove saline effluents. Physical and chemical processes are difficult to run with high set-up and operation costs, consume high amount of chemicals and energy and produce by-products, which results in secondary pollution of possible chemical residues [8]. By contrast, biological processes with simpler operation but high efficient and effective cost are often used. A variety of microbial consortia were employed to degrade the target

This research received the sponsor from The Foundation for Science and Technology and DOST of Tien Giang province-Vietnam 
Le Hung Anh et al., International Journal of Emerging Trends in Engineering Research, 8(10), October 2020, 7179 - 7185

contaminants [9]. The treatment again has to face the main problem that the reduction of metabolism activities of microbes will occur in the hypersaline environment because salt concentrations $(>1 \%)$ can cause primary contraction, plasmolysis, loss of cell functions and even cell deaths [10]. The presence of high amounts of recalcitrant organics and chlorinated hydrocarbons in wastewater results in low $\mathrm{BOD}_{5} / \mathrm{COD}$ ratio, low treatment yield and bulking of activated sludge at the end of the treatment [11], [12].

Salt-tolerant microorganisms are the good candidates to tackle the treatment problem. They live in the medium with the salinity under $1 \%$ but can endure the salt-rich environment owing to special metabolic mechanisms [13]. According to salt requirements and the extent of halotolerance, they can be divided into five categories: (1) nonhalophiles (below $0.2 \mathrm{M} \mathrm{NaCl}$ ); (2) halo-tolerant (nonhalophiles but can tolerate large salt amount); (3) slight halophiles $(0.2-0.5 \mathrm{M} \mathrm{NaCl})$; (4) moderate halophiles $(0.5-$ $2.5 \mathrm{M} \mathrm{NaCl}$ ); and (5) extreme halophiles (above 1-1.5\% equivalent to $2.5-5.5 \mathrm{M} \mathrm{NaCl}$ for survival and above $2 \%$ for the optimal growth) [14]. Halophiles maintain an osmotic balance between the cytoplasm and external environment by accumulating soluble inorganic ions such as $\mathrm{K}^{+}, \mathrm{Na}^{+}$and $\mathrm{Cl}^{-}$ in the cytoplasm and producing proteins stable and active in the saline medium [15], while moderate halophiles accumulate osmolytes acting as osmoprotectants to balance the osmotic pressure [16].

The number of studies on application of halophilic bacteria in saline wastewater treatment is increasing recently. Kargi and Dincer (2000) obtained good treatment performance of wastewater with the salinity of over $2 \%$ when using salttolerant bacteria in activated sludge [17]. Sivaprakasam et al. (2008) isolated halophilic microorganisms from seawater, marine soil, salt lake water $(15 \%$ and $20 \% \mathrm{NaCl} w / v)$ and salt lake sediment clay in India and applied successfully these halophiles in tannery wastewater treatment [18].

This study aims to isolate several salt-tolerant bacteria from aquafarming wastewater collected in Tien Giang, Vietnam. Microbial strains were cultured in BMS medium at $30^{\circ} \mathrm{C}, \mathrm{pH}$ 7.0 and identified by MALDI-TOF. An experimental model was assembled to investigate the COD removal ability of the characterized bacteria at different ratios of bacteria and aquafarming wastewater in the laboratory.

\section{METHODS}

\subsection{Sampling and designing experimental model}

The wastewater was collected in two places - Vam Lang fishing port in Tien Giang province and Minh Thang seafood processing company in Vam Lang town, Go Cong Dong, Tien Giang province. The parameters ( $\mathrm{pH}, \mathrm{DO}, \mathrm{COD}$, total $\mathrm{P}$, $\mathrm{N}$ and $\mathrm{Cl}^{-}$were tested to give the first insight about water quality that was the cornerstone to design the following experiments.
The experimental model illustrated in Figure 1 includes 10 reaction compartments with the continuous aeration by using air distribution bar at the bottom of the compartments and aeration pump system during the experiments. Each compartment has the dimensions $7 \mathrm{~cm}$ (length) x $12.5 \mathrm{~cm}$ (width) x $10.5 \mathrm{~cm}$ (height) and contained $500 \mathrm{~mL}$ of water samples.

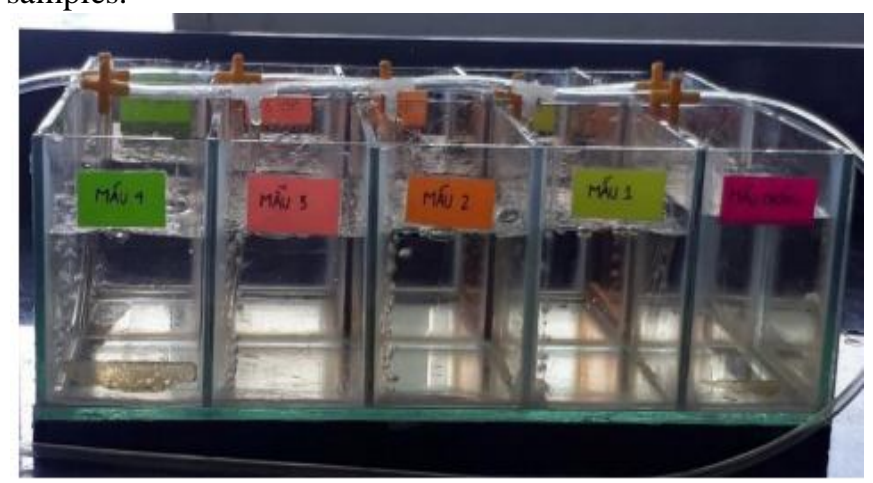

Figure 1. Experimental model of wastewater treatment

\subsection{Isolation of salt-tolerant microorganisms}

The saline wastewater was diluted with physiologic sodium chloride solution $(0.9 \%)$. A suitable aliquot of the mixture was dropped in the BMS medium containing $3 \mathrm{~g} / \mathrm{L} \mathrm{NaNO}_{3}, 1$ $\mathrm{g} / \mathrm{L} \mathrm{KH}_{2} \mathrm{PO}_{4}, 0,5 \mathrm{~g} / \mathrm{L} \mathrm{MgSO}{ }_{4}, 0,5 \mathrm{~g} / \mathrm{L} \mathrm{KCl}, 5 \mathrm{~g} / \mathrm{L} \mathrm{NaCl}, 1 \mathrm{~g} / \mathrm{L}$ yeast extract and $20 \%$ agar in sterile Petri dishes. The culture was incubated at $37^{\circ} \mathrm{C}$ in 24 hours. Separated clear colonies were selected and sub-cultured until the pure colonies were obtained.

\subsection{Selection and identification of salt-tolerant bacteria}

The isolated species were cultured in BMS medium supplied with $\mathrm{NaCl}$ at different rates: 1, 3, 5 and $7 \%$. The development of colonies was observed and colonies with the highest salt tolerance were selected for identification. The bacterial characterization was carried out by protein mass spectroscopy method with MALDI-TOF Matrix Assisted Laser Desorption Ionization-Time of Flight.

\subsection{Investigation of COD removal performances in saline wastewater}

The experimental model (Figure 1) was used to investigate the effects of input amount of bacteria as the treatment agent, input COD amount of the wastewater to find out the best solutions for treating seafood processing wastewater collected in Tien Giang province, particularly:

- Determine the best ratio of species to wastewater by testing at four ratios: 1:5, 1:10, 1:15 và 1:20 in volume during 96 hours.

- Determine the maximum COD threshold that can be adapted by halophiles, and the removal ability of each individual species during the period from 24 to 96 hours.

- Determine the effectiveness of combining species depending on their functions. The treatment yield were calculated in the period from 24 to 96 hours. 
Le Hung Anh et al., International Journal of Emerging Trends in Engineering Research, 8(10), October 2020, 7179 - 7185

\section{RESULTS AND DISCUSSION}

\subsection{Isolation of salt-tolerant microorganisms}

Table 1. Input quality of wastewater

\begin{tabular}{|c|c|c|}
\hline Parameters & $\begin{array}{c}\text { Vam Lang } \\
\text { fishing port }\end{array}$ & $\begin{array}{c}\text { Minh Thang } \\
\text { factory }\end{array}$ \\
\hline COD $(\mathrm{mg} / \mathrm{L})$ & 3195 & 4254 \\
\hline Total P $(\mathrm{mg} / \mathrm{L})$ & 54,2 & 84 \\
\hline Total $\mathrm{N}(\mathrm{mg} / \mathrm{L})$ & 87,4 & 675 \\
\hline $\mathrm{pH}$ & 8,1 & 8,4 \\
\hline $\mathrm{DO}(\mathrm{mg} / \mathrm{L})$ & 3,03 & 0,2 \\
\hline $\mathrm{Cl}^{-}(\mathrm{mg} / \mathrm{L})$ & 6523 & 9851 \\
\hline
\end{tabular}

Table 2 is the list of 45 microbial species in total was isolated from 10 wastewater samples with the quality described in Table 1. In all parameters, COD and chloride concentrations were significant high.

Table 2. The list of microbial strains isolated from 10 wastewater samples

\begin{tabular}{|c|c|c|}
\hline Wastewater & Number of strains & Symbols \\
\hline 1A & 3 & $1 \mathrm{~A} 1 \rightarrow 1 \mathrm{~A} 3$ \\
\hline 1B & 5 & $1 \mathrm{~B} 1 \rightarrow 1 \mathrm{~B} 5$ \\
\hline $1 \mathrm{C}$ & 4 & $1 \mathrm{C} 1 \rightarrow 1 \mathrm{C} 4$ \\
\hline $2 \mathrm{~A}$ & 5 & $2 \mathrm{~A} 1 \rightarrow 2 \mathrm{~A} 5$ \\
\hline $2 \mathrm{~B}$ & 4 & $2 \mathrm{~B} 1 \rightarrow 2 \mathrm{~B} 4$ \\
\hline $2 \mathrm{C}$ & 3 & $2 \mathrm{C} 1 \rightarrow 2 \mathrm{C} 3$ \\
\hline $3 \mathrm{~A}$ & 5 & $3 \mathrm{~A} 1 \rightarrow 3 \mathrm{~A} 5$ \\
\hline $3 \mathrm{~B}$ & 3 & $3 \mathrm{~B} 1 \rightarrow 3 \mathrm{~B} 3$ \\
\hline $4 \mathrm{~A}$ & 7 & $4 \mathrm{~A} 1 \rightarrow 4 \mathrm{~A} 7$ \\
\hline $4 \mathrm{~B}$ & 6 & $4 \mathrm{~B} 1 \rightarrow 4 \mathrm{~B} 6$ \\
\hline
\end{tabular}

The color, homogeneity and surface of colonies were described in Figure 2 and was compared with the standard species in the literature. The cell strains appeared in flat or convex round with slightly marginal edge. The colonies looked like spreading-out root with smooth or slightly wrinkled surface, and had transparent white, milky white, light yellow or orange colors. These colors were fairly similar to those mentioned in the studies of Oren et al. $(1986,1992)$ [19], [20], which are transparent white, white, opalescent white, light yellow, yellow and orange colors depending on the carotenoid in their cells.
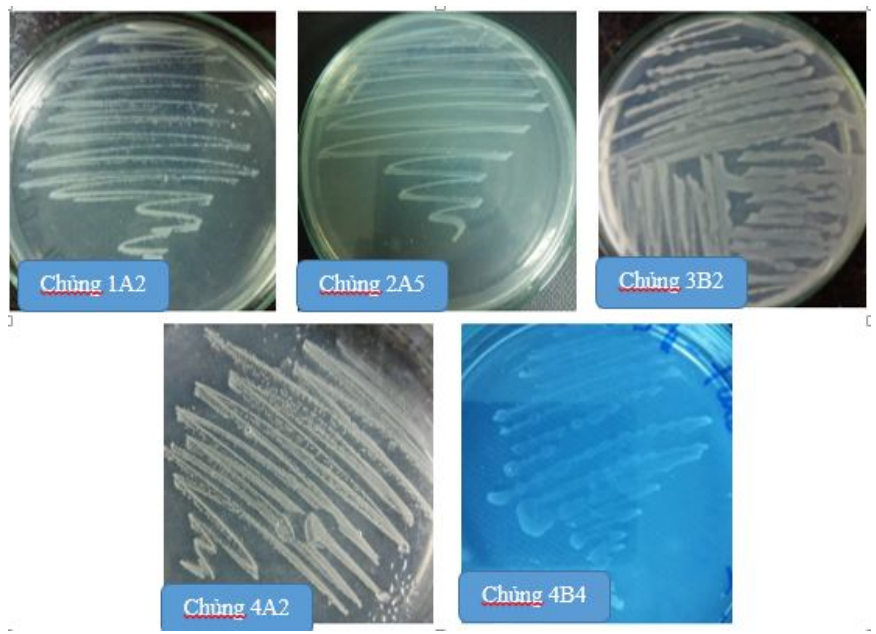

Figure 2. The description of microbial colonies isolated from 10 wastewater samples
According to Larsen et al., 1962, the change of colors was also affected by the salinity of the medium, in which they appear in few colors, such as cream or yellow [15]. In addition, mucosa were found in some colonies with the protrusive or expanded leading edges. The size of cells was smaller or more sensitive in the saltier environment, particularly in the micro-size, which made the cell staining more difficult. After 24 - 36 hours, mature colonies were found in the attachment to the surface of agar medium.

\subsection{Identification of isolated salt-tolerant bacteria}

As shown in in Figure 3, all 45 strains were developed well in the medium containing $1 \% \mathrm{NaCl}$. However, only 33 strains could develop in higher medium with $3 \% \mathrm{NaCl}$ after 24-hour culture. In higher saline concentration, their growth rate reduced, and after 45 hours, only 14 strains and 12 strains could live in the environment with the salinity of 5 and $7 \%$, respectively. The high salinities caused direct impacts on transferring ions in and out of the cell membrane, affecting on the osmotic pressure of the membrane. Only three strains $1 \mathrm{~B} 1,2 \mathrm{~A} 2,3 \mathrm{~A} 5$ grew up most strongly in these hypersaline media. The lowest proliferation in the $7 \%$ salinity was observed at $1 \mathrm{~B} 5$ and $3 \mathrm{~A} 3$ of 12 strains.

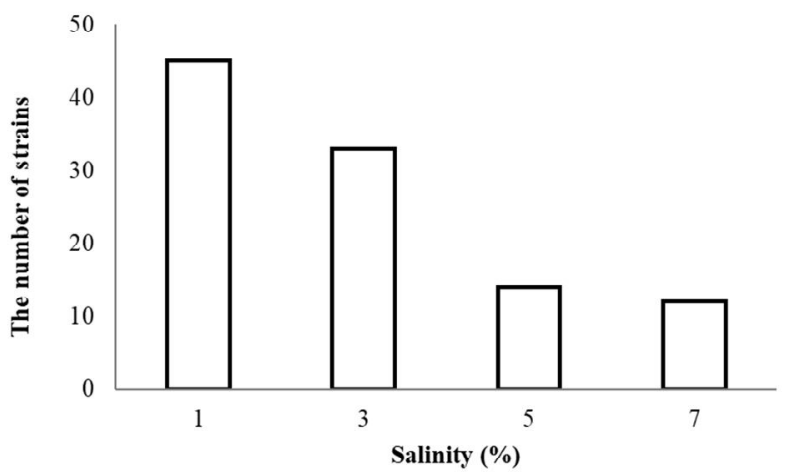

Figure 3. The salt tolerance of strains isolated from saline wastewater

Strains isolated from different samples belonged to halophilic species with various colors and cellular morphologies. The appearance of colonies was not enough to distinguish microbial species and to determine the exact species' names because morphological characteristics depend on growth conditions and change by the change of saline concentrations, temperature, $\mathrm{pH}$, and other components of the medium [21]. Therefore, the strains were determined based on the mass spectroscopic measurement of proteins produced by the colonies in the typical medium by MALDI-TOF. This technique is less time-consuming and cost-effective compared with PCR and gene sequencing methods that are based on the gen bank to conclude the microbial species. Thus, ten strains 1B1, 1C2, 2A2, 2B1, 2B3, 3A5, 3B3, 4A1, $4 \mathrm{~A} 7,4 \mathrm{~B} 6$ which could survive in the medium of $7 \%$ salinity were selected for identification with MALDI-TOF.

The bacterial names were called in Table 3 based on the mean of score values of similarity coefficients produced from the instrument software. If the coefficients fall in the range of $2.3-3.0$, marked as (+++), the sample species are highly 
Le Hung Anh et al., International Journal of Emerging Trends in Engineering Research, 8(10), October 2020, 7179 - 7185

probable with the standard species. The range of $2.0-2.299$ marked (++) means secure genus identification and probable species identification. The decreased coefficients show the less possibility of identification. The coefficients in the range of $1.7-1.999$ indicate the probable genus identification $(+)$. Finally, when the coefficients are less than 1.699 , marked (-), there are no reliable identifications, and strains having score values in this range were negligible.

Table 3. Identification of ten salt-tolerant bacteria isolated from wastewater

\begin{tabular}{|c|c|c|c|}
\hline Strains & $\begin{array}{c}\text { Proposed } \\
\text { species' name }\end{array}$ & $\begin{array}{c}\text { Similarity } \\
\text { coefficients }\end{array}$ & Degree \\
\hline 1B1 & $\begin{array}{c}\text { Staphylococcus } \\
\text { epidermidis }\end{array}$ & 2.17 & ++ \\
\hline 1C2 & $\begin{array}{c}\text { Micrococcus } \\
\text { luteus }\end{array}$ & 2.22 & ++ \\
\hline 2A2 & $\begin{array}{c}\text { Bacillus } \\
\text { lichiniformis }\end{array}$ & 1.93 & + \\
\hline 2B1 & $\begin{array}{c}\text { Bacillus } \\
\text { lichiniformis }\end{array}$ & 2.21 & ++ \\
\hline 2B3 & Bacillus subtilis & 1.73 & + \\
\hline 4A1 & Bacillus subtilis & 2.11 & ++ \\
\hline 4A7 & Bacillus subtilis & 1.57 & - \\
\hline 4B6 & Bacillus cereus & 2.23 & ++ \\
\hline 3A5 & $\begin{array}{c}\text { Arthrobacter } \\
\text { creatinolyticus }\end{array}$ & 1.96 & + \\
\hline 3B3 & $\begin{array}{c}\text { Lactobacillus } \\
\text { pentosus }\end{array}$ & 1.52 & - \\
\hline
\end{tabular}

Bacteria cannot perform phagocytosis because of hard cell walls. Instead, they secrete enzymes such as proteolytic protease enzymes, amylases to hydrolyze large macromolecules into smaller molecules that will then be transported into the cell for the cellular metabolism. Most species of salt-loving bacteria are aerobic or aerotolerant anaerobes. Gram-negative bacteria are believed to be members of different genera Halomonas, Deleya, Volcaniella, Flavobacterium, Paracoccus, Pseudomonas, Halovibrio, or Chromobacterium. Based on their phenotypic and phylogenetic data, they have closely relations and are grouped in Halomonadaceae family consisting of two genera: Halomonas and Chromohalobacter. Gram-positive bacteria include Bacillus, Halobacillus, Marinococcus, Salinicoccus, Nesterenkonia, Tetragenococcus, Actinopolyspora and Nocardiopsis.

Among species, Staphylococcus sp. has commonly been isolated from soil and wastewater with the halophilic characteristics and thereby applied in hypersaline wastewater treatment in several studies. For example, Kubo et al. (2001) isolated Staphylococcus sp. and Bacillus cereus from soil that could grow well in the environment having up to $15 \%$ salinity and successfully applied in treatment of grape-production wastewater in Japan [22]. Ganzert et al. (2011) isolated Arthrobacter from salt-contaminated soil; however, they did not found Arthrobacter creatinolyticus as our study [23].

Most recently, Pham Kim Lien and Nguyen Bang Phi (2017) from Thu Dau Mot University (Vietnam) has successfully used Bacillus subtilis to treat domestic wastewater in Thu Dau Mot city [24]. The genus Bacillus is known for diverse strains of bacteria with high adaptability and can use various sources of $\mathrm{C}, \mathrm{N}$ nutrients. On the other hand, this genus has the ability to produce spores under the harsh conditions including high-salt-content environment. Indeed, among 10 named strains, 6 strains of Bacillus genus were found to be able to grow relatively well in $7 \%$ salinity, with the optimal $3-5 \% \mathrm{NaCl}$.

Halophiles have the ability to change their properties with living conditions. An osmotic balance must be established between the intracellular and external environment of the microbial cells in order to resist high salinity and frequent fluctuations of salt concentrations. By this way, they can be resistant to the high osmotic pressure in the environment. This balance is established by the accumulation of salts and dissolved organic matter [16] and itself controlling the movement of water in and out of the cells to keep the osmotic balance in the intracellular space. The natural water in Tien Giang belongs to Mekong River. However, the current salt intrusion has caused the unstable salt concentrations in the water here, and salt-tolerant bacteria could adapt to the salt fluctuations thanks to these special mechanisms.

\subsection{Determination of the best seed rate of bacterial species for saline wastewater}

The change of concentration ratio of bacteria and wastewater affected the COD removal yields in the same treatment time of 96 hours, which was illustrated in Figure 4. The highest treatment yield was observed in strain 1C2 (reduced by $100 \%$ COD) at the ratio of 1: 5. The color of treated wastewater was much clearer than that of other samples. At the seed rate of 1:10, treatment efficiencies varied from $78.77 \%$ to $90.15 \%$, except that strain $3 \mathrm{~A} 5$ gave low yield of only $50.77 \%$. At the seed rates 1:15 and 1:20, COD treatment efficiencies were generally low, compared with the higher ratios. This could be because the amount of treatment agent (bacteria) was lower to some extent than the amount of organic substances in the wastewater. The lowest yield was $33.92 \%$ at $1: 20$ ratio of strain 3B3.

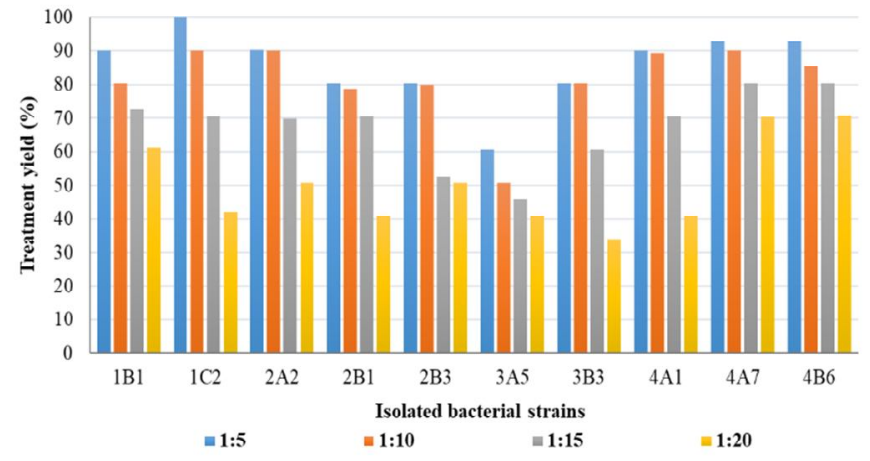

Figure 4. Effects of the seed rates on COD removal yields As can be seen from Figure 4, at the seed rate of 1:5, the treatment yields of Micrococcus luteus (1C2) were highest, which reached $100 \%$, followed by Bacillus subtilis (4A7), 
Le Hung Anh et al., International Journal of Emerging Trends in Engineering Research, 8(10), October 2020, 7179 - 7185

Bacillus cereus (4B6) with $92.77 \%$ and Staphylococcus epidermidis (1B1) with $90.15 \%$. In a general overview, Bacillus sp. strains (2B3, 4A1, 4A7, 2A2 và $2 \mathrm{~B} 1)$ gave high treatment abilities (over $70 \%$ ) at seed rates of more than 1:15. Only three strains of Staphylococcus epidermidis and Bacillus subtilis were able to remove COD by over $60 \%$ even in the low input cell concentrations (1:20 ratio). The good treatment performance of Staphylococcus sp. and Bacillus sp. has also discovered in previous studies. Motoki Kubo et al. (2001) also reported Staphylococcus sp. and Bacillus cereus isolated from the grape processing plant could reduce $70 \%$ COD of salty wastewater after 72 hours and up to $90 \%$ when applied at a pilot scale with the $1 \mathrm{~m}^{3}$ water volume for 7 days in the factory [22]. Sohair I. AbouElea et al. (2009) used Staphylococcus xylosus isolated from agricultural processing wastewater with activated sludge containing 3\% salinity to get the yield of $90 \%$ [25]. Moreover, Staphylococcus sp. BH4; yeast Candida sp. YH; Desulfovibrio sp. $\mathrm{BH}$ and salt-tolerant Anammox bacteria were able to adapt to the saline concentration of $5-10 \mathrm{~g} / \mathrm{L}$ in wastewater and remove by $70-80 \%$ COD in average [26].

On the whole, Micrococcus sp., Staphylococcus sp., and Bacillus sp. were great candidates for treatment of seafood processing wastewater at the ratio of 1:5.

\subsection{Determination of the COD tolerance and removal of each bacterial strain}

In addition to the seed rates, the COD of input wastewater should be taken into account. Although microorganisms can absorb certain kinds of organic pollutants, they will be overwhelmed if the organic amounts are too high. Thus, a limit COD input of $500 \mathrm{mg} / \mathrm{L}$ is recommended for biological treatment methods. Besides, chloride concentration play a vital of role in inhibiting the microbial proliferation. Results of the preliminary tests show considerable differences in organic treatment of 10 bacterial strains at two COD levels 200 and $400 \mathrm{mg} / \mathrm{L}$ during the exposure time of 24, 48, 72 and 96 hours.

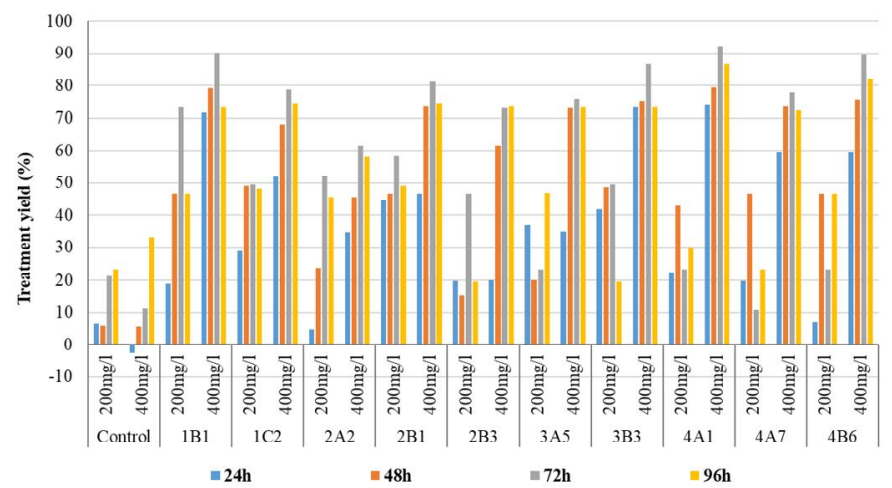

Figure 5. COD removal of individual bacterial species by the time

At the low COD content of $200 \mathrm{mg} / \mathrm{L}$, the highest treatment efficiencies were $73.33 \%$ for strain 1B1 (Staphylococcus epidermidis) in 72 hours. However, the yield increased by the increase of COD content in the same treatment period, particularly, $90 \%$. At this level, strain 4A1 (Bacillus subtilis) gave the highest yields after 48 hours compared with other strains (Figure 5).

In terms of treatment time, at the COD level of $200 \mathrm{mg} / \mathrm{L}$, the yields started increasing only more than 48 hours. Strains 1B1, 1C2, 2A2, 2B1, 2B3, 3A5, 3B3 achieved the highest efficiencies after 72 hours, then the yields decreased by the time. Nevertheless, the yields of three strains 4A1, 4A7, 4B6 were highest in after 48 hours, then decreased if the treatment was continued lasting. The COD efficiencies were highest at 72 hours in all strains especially Staphylococcus epidermidis and Bacillus subtilis, maximum of $92.14 \%$ for $4 \mathrm{~A} 1$ and minimum of $73.08 \%$ for $2 \mathrm{~B} 3$. Again, these two bacterial species were mentioned with their great COD removal performances. Staphylococcus sp. and Bacillus cereus were applied in grape processing wastewater treatment by Kubo $e t$ al., 2001. The COD levels were reduced by $70 \%$ after 72 hours in a treatment pilot and by up to $90 \%$ after 7 days in the practical scale of $1 \mathrm{~m}^{3}$ in the plant [22].

\subsection{Effectiveness of combination of strains in COD removal from saline wastewater}

Based on the COD removal ability of each individual species, strains were selected to combine and classified into three groups:

- Group 1 includes 5 strains with the highest treatment yields: 1B1, 2B1, 3B3, 4A1 and 4B6.

- Group 2 consists of 5 strains with the best salt tolerance: 1B1, 1C, 2A2, 3A5 and 4A7.

- Group 3 is a simple combination of 10 strains.

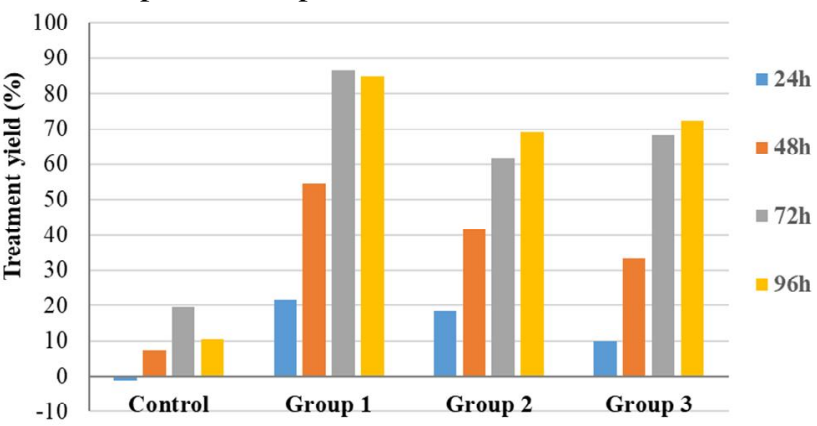

Figure 6. COD treatment of combined bacterial species It is obviously seen that combining bacteria with great treatment abilities could give better than the mixture of salttolerant species and the random combination. Particularly, the yield of group 1 was higher four times than the control samples. Furthermore, there was no noticeable difference about the exposure time from 72 hours in all groups. The efficiencies of both group 2 and 3 were similar and increased significantly compared with the control if the incubation time was expanded (from 24 hours). This phenomenon highlighted the key role of salt-tolerant species in the removal of organic compounds in saline aquafarming wastewater taken in Tien Giang province of Vietnam.

\section{CONCLUSION}

A total of 45 microbial strains were isolated from 10 saline wastewater samples. The investigation showed all 45 strains 
Le Hung Anh et al., International Journal of Emerging Trends in Engineering Research, 8(10), October 2020, 7179 - 7185

proliferated very well in the presence of $1 \% \mathrm{NaCl}$. The number of survival rate decreased by the increase of the salinity. 33 strains could grow at $3 \%$ salinity, 14 strains develop fairly well at the salinity of $5 \%$, and only 12 strains could multiple at the saline concentration of $7 \%$. From the salt tolerance outcomes, 10 strains with the greatest salt tolerance was chosen - 1B1, 1C2, 2A2, 2B1, 2B3, 3A5, 3B3, 4A1, 4A7, 4B6 strains that could endure the medium containing $1-7 \%$ salinity and develop after 24 hours at $30^{\circ} \mathrm{C}$ and $\mathrm{pH}$ 7. The MALDI-TOF results showed the selected strains belonged to genus Arthrobacter, Micrococcus Staphylococcus, Bacillus and Lactobacillus.

The first evaluation showed all 10 strains were able to reduce COD level in the $3 \%$ saline mixture. To obtain the best treatment efficiency, bacterial strains should be mixed with the waste water at the ratio of 1:5 and incubated for at least 96 hours in the continuous aeration. As a result, Micrococcus luteus (1C2 strain) gave the most effective treatment while the COD removal ability of 3A5 strain (Arthrobacter creatinolyticus) was lowest. Other strains produced relatively high treatment efficiencies in general at the seed rate of 1:5.

\section{ACKNOWLEDGEMENT}

The authors would like to express the sincere appreciation to The Foundation for Science and Technology and DOST of Tien Giang province-Vietnam for the financial support in carrying out this research.

\section{REFERENCES}

1. Lefebvre, O., Moletta, R.. Treatment of organic pollution in industrial saline wastewater: a literature review, Water Ref., Vol. 40, pp. 3671-3682, Dec 2006.

2. Le Hung Anh and Vo Thi Kim Khuyen. Biotreatment Of Aquaculture Wastewater With Chlorella Sp. In Tubular Photo-Bioreactors, IJSTR, Vol. 9, pp. 10081013, Apr. 2020.

3. APHA, AWWA, WEF, Standard Methods for the Examination of Water and Wastewater, 22th ed., American Health Public Association, Washington, DC, 2012.

4. Negar Basereh Taromsary, Babak Bonakdarpour, Mohammad Ali Amoozegar, Narges Fallah, Arezou Fadaei Tehran. Quantifying the organic content of saline wastewaters: Is chemical oxygen demand always an achievable parameter?, Talanta, Vol. 197, pp. 509-516, Jan. 2019.

5. Y.C. Ching, G. Redzwan. Biological treatment of fish processing saline wastewater for reuse as liquid fertilizer. Sustainability, Vol. 9, pp. 1-26, June 2017.

6. Y. Xiao, D.J. Roberts. A review of anaerobic treatment of saline wastewater, Environ. Technol., Vol. 31, pp. 1025-1043, Aug. 2010.

7. E.R. Burns, C. Marshall. Correction for chloride interference in the chemical oxygen demand test, $J$. Water Pollut. Control Fed., Vol. 37, pp. 1716-1721, Dec. 1965.
8. Kim, H.-C., Choi, W.J., Chae, A.N., Park, J., Kim, H.J., Song, K.G., 2016. Treating highstrength saline piggery wastewater using the heterotrophic cultivation of Acutodesmus obliquus, Biochem. Eng. J., Vol. 110, pp. 51-58, June 2016.

9. Pronk, M., Bassin, J., De Kreuk, M., Kleerebezem, R., Van Loosdrecht, M.,. Evaluating the main and side effects of high salinity on aerobic granular sludge, Appl. Microbiol. Biotechnol., Vol. 98, pp. 1339-1348, May 2013.

10. Jiang, D., Hwang, Y., Shin, H., Lee, W.. Effects of salinity on the characteristics of biomass and membrane fouling in membrane bioreactors, Bioresour. Technol., Vol. 141, pp. 50-56, Aug. 2013.

11. Xiaohui Zhang, Jie Gao, Fangbo Zhao, Yuanyuan Zhao, Zhanshuang Li. Characterization of a salt-tolerant bacterium Bacillus sp. from a membrane bioreactor for saline wastewater treatment, J. Environ Sci, Vol. 26, pp. 1369-1374, June 2014.

12. Jemli, M., Karray, F., Feki, F., Loukil, S., Mhiri, N., Aloui, F., Sayadi, S., Biological treatment of fish processing wastewater: a case study from Sfax City (Southeastern Tunisia), J. Environ. Sci., 30, 102-112, Apr. 2015.

13. Darvishi Cheshme Soltani, R., Rezaee, A., Godini, H., Khataee, A.R., Jorfi, S. Organic matter removal under high loads in a fixed-bed sequencing batch reactor with peach pit as carrier, Environ. Prog. Sustain Energy, Vol. 32, pp. 681-687, Aug. 2012.

14. Mehdi Ahmadi, Sahand Jorfi, Raheleh Kujlu, Shokouh Ghafari, Reza Darvishi Cheshmeh Soltani, Nematollah Jaafarzadeh Haghighifard. A novel salt-tolerant bacterial consortium for biodegradation of saline and recalcitrant petrochemical wastewater, $J$. Environ Manage., Vol. 191, pp. 198-208, Apr. 2017.

15. Larsen. Halophilism, The Bacteria, Vol. 4, Academic Press, pp. 297-342, 1962.

16. Bassam Oudh Aljohny. Halophilic Bacterium - A Review of New Studies, Biosciences Biotechnology Research Asia, Vol. 12, pp. 2061-2069, December 2015.

17. Kargi F., Dinc, er, A.R.,. Use of halophilic bacteria in biological treatment of saline wastewater by fedbatch operation, Water Enviro. Res., Vol. 72, pp. 170174, Apr. 2000.

18. Senthilkumar Sivaprakasam, Surianarayanan Mahadevan, Sudharshan Sekar and Susheela Rajakumar. Biological treatment of tannery wastewater by using salt-tolerant bacterial strains, Microb Cell Fact, Vol. 7, pp. 1-7, Apr. 2008.

19. Oren A., Intracellular salt concentrations of the anaerobic halophilic eubacteria Haloanaerobium praevalens and Halobacteroides halobius, Can J Microbiol, Vol. 32, pp. 4-9, 1986.

20. Oren, A., P. Gurevich, M. Azachi, and Y. Henis. Microbial degradation of pollutants at high salt concentrations, Biodegradation, Vol. 3, pp. 387-398, 1992. 
21. Aneela Roohi, Iftikhar Ahmed, Muhammad Iqbal and Muhammad Jamil. Preliminary isolation and characterization of halotolerant and halophilic bacteria from salt mines of karak, Pakistan, Pak. $J$. Bot., Vol. 44, pp. 365-370, Mar. 2012.

22. Motoki Kubo, Jyunichi Hiroe, Makoto Murakami, Hiroshi Fukami, Takashi Tachiki. Treatment of Hypersaline- Containing Wastewater with SaltTolerant Microorganisms, Journal Of Bioscience And Bioengineering, Vol. 91, No. 2, 222-224. 2001.

23. Lars Ganzert, Felizitas Bajerski, Kai Mangelsdorf, André Lipski and Dirk Wagner. Arthrobacter living stonensis sp. nov. and Arthrobacter cryotolerans sp. nov., salt-tolerant and psychrotolerant species from
Antarctic soil. International Journal of Systematic and Evolutionary Microbiology, Vol. 61, pp. 979-984, Apr. 2011.

24. Phạm Kim Liên và Nguyễn Bằng Phi. Nghiên cứu xử lý nước thải sinh hoạt của xí nghiệp nước thải Thủ Dầu Một bằng vi khuẩn Bacillus subtilis, Journal of Thu Dau Mot university, Vol. 4, pp. 16-22, Apr. 2017.

25. Sohair I. Abou-Elela, Mohames M. Kamel, Mariam E. Fawzy. Biological treatment of saline wastewater using a salt-tolerant microorganism, Elsevier, Vol. 250, pp. 1-5, Jan. 2010.

26. Trần Minh Chí. Nghiên cứu kỹ thuật sử dụng các chế phẩm sinh học xử lý nước trong nuôi trồng thủy sản vùng ĐBSCL, KCO8. Vol. 26, 2015. 